obtained high emission, but only at very high vacuum; the latter has worked at the vacuum more usually prevailing in a demountable apparatus, obtaining so far only small beam currents. In view of the difficulty of obtaining stable field emission in such circumstances, it appears at present that the best prospect for increased intensity in the point-focus tube lies in correction of the spherical aberration of the magnetic lens. The projection method has the advantage of direct enlargement on normal emulsions, but at cost of small field of view ; the contact method gives a large field, but has greater difficulties of specimen preparation (since the specimen has to be very thin and placed almost directly on the emulsion) and of photographic processing. Even if a grainless film of reasonable speed can be developed, the optical viewing system will impose a limit on resolution-unless the emulsion can be stripped and viewed in the electron microscope. A possible technique of this nature was described by Dr. W. A. Ladd (Ladd Research Industries, New York), in which the 'emulsion' is a plastic film in which $\mathrm{X}$-rays produce solubility changes depending on amount of exposure.

Even though $\mathrm{X}$-ray methods may equal and perhaps exceed the optical resolving power, their main value in biology is likely to lie in the ability to distinguish different elements in the specimen, by means of differential absorption, emission and fluorescence. A large number of contributions was devoted to these methods of quantitative analysis. The Stockholm school has investigated in detail the accuracy attainable in absorption spectrophotometry, utilizing the characteristic absorption edges of the different elements. Dr. B. Lindström reported on analysis of sulphur and phosphorus in biological material, using a new high-vacuum apparatus and soft X-rays, and Dr. G. Wallgren described his studies in the mineralization of developing bone in human embryos. By direct microphotometry, analyses can be carried out on areas of tissue down to $3 \mu^{2} ;$ a scanning and computing instrument for this purpose was described by Dr. O. Hallen (University of Gothenburg).

The projection method can also be adapted to microanalysis, and is especially useful for areas smaller than a few square microns, since photometry or photon-counting is carried out directly on an enlarged image. Mr. P. Duncumb (Cambridge) dealt with the design and operation of a flying-spot system for the analysis of thin layers by X-ray emission : the characteristic lines are detected and their strength measured by a proportional counter. An accuracy approaching 1 per cent can be obtained with a spot $1 \mu$ in diameter, and neighbouring elements in the periodic table can be separated if a crystal spectrometer is used. Mr. J. V. P. Long (Cambridge) described the adaptation of a projection X-ray microscope for the analysis of selected regions of a specimen, under a stationary spot, by fluorescence, absorption or emission methods at will. In emission, the specimen can simultaneously be viewed in transmitted light by an optical microscope. The limits of microchemical analysis by these methods were discussed by Prof. A. V. Baez (Redlands University, California). A detection limit of $I$ per cent in a volume of $1 \mu^{3}$ is equivalent to a mass sensitivity of $10^{-14} \mathrm{gm}$. of substance of unit density. At the moment, it is possible to determine elements of medium atomic number, down to aluminium or perhaps magnesium. Prof. Engström and Dr. Henke discussed the practicability of analysing separately the carbon, oxygen and nitrogen content of biological tissues with very soft $X$-rays, and it appears that this may be done with an accuracy of $5-10$ per cent. Such a technique will be of revolutionary value in cytochemistry, just as the qualitative results obtained with microradiography are creating a new subject of microanatomy.

The sessions on applications of X-rays to microscopy, at the moment primarily using the contact method, covered a very wide range of subjects at the symposium. In biology, reports were presented of work on plant cancers and the growth of inorganic crystals in leaves, on the progress of osmium fixation in tissues, on the microstructure of wood and on insect flight musculature. In the medical field, investigations were reported of cancer of the breast and of the cervix, the human eye, the vascular patterns of human muscle and skin, growth of stone in the kidney and the embryonic stages of dentition. New techniques are now making it possible, particularly with the projection method, to observe changes in living tissue under experimental treatment. The metallurgical session was shorter, but contained accounts of the use of microradiography in studying segregation effects in ferrous metals and in light alloys, especially of aluminium, and the growth of oxide films. Preliminary studies of the distribution of heavy elements in rock sections were also reported.

Some discussion took place, formally and informally, on the need for further meetings on the subject of X-ray microscopy, for a specialized abstracting service and for clearing up matters of terminology. A small committee was set up to look into possible forms of organization, with particular regard to existing bodies and the need for connexion with the International Council of Scientific Unions. Its report will be prepared in time for discussion at the next symposium, which it is hoped to hold in Stockholm in $1959 . \quad$ V. E. CossLetT

\section{THE EIGHTEENTH INTERNATIONAL GEOGRAPHICAL CONGRESS}

THE eighteenth International Geographical Congress was held in Rio de Janeiro during August 918. The 1,006 delegates actually present included nearly four hundred from overseas, representing more than forty countries. The first congress was in 1871, yet this was the first to be held in the southern hemisphere, the first in the Tropics and the first in Latin America. It was opened in a blaze of pageantry by the President of Brazil in person at the Municipal Opera House. The delegates were welcomed by the President of the Organizing Committee of the Brazilian National Committee for Geography, and the British President of the International Geographical Union (Prof. L. Dudley Stamp, elected at Washington in 1952) gave a précis of his presidential address on the "Measurement of Land Resources". In order to secure some more precise measure of the capability of different types of land in differing climates and under differing types of management to support human life, he suggested the introduction of a 'Standard Nutrition Unit' of $1,000,000$ calories annual production or 900,000 calories of net annual consumption. It was shown that a varied diet based largely on meat may require $3 \frac{\lambda}{2}$ acres or more to 
produce one such unit, whereas with an extreme concentration on high-calorie foods (for example, rice and sweet potatoes) and intensive multiple cropping, as many as $6 \frac{1}{2}$ units per acre are produced in Japan, or more than twenty times as much.

At the first session of the General Assembly, four countries were elected to full membership-the U.S.S.R. (which had sent a strong delegation), Iceland, Hungary and Ethiopia. This was the first participation of the Russians since before the Second World War. With the object of helping the development of geographical research in countries with an insufficient number to set up the National Committee required of adhering nations, the General Assembly added to the Statutes provision for a class of Associate Members and elected as such the Sudan, French West Africa, Nigeria, Uganda, Kenya and Iraq.

More than three hundred papers, printed in abstract in advance, were presented to the dozen working sections into which the Congress was organized. Much attention was also given to the presentation and discussion of commission reports. At each Congress, the General Assembly, with the guidance of the Executive Committee, appoints commissions, consisting of not more than six full members, to carry out investigations into specific problems. Each commission must present a report at the next Congress, but may be reappointed for a further term. Reports presented were those on Medical Geography (which also had an active and flourishing section dealing both with the geographical distribution of disease and relevant factors), Evolution of Slopes, Erosion Surfaces around the Atlantic, Coastal Sedimentation, Periglacial Phenomena, Karst Phenomena, Arid Zones, the Library Classification of Geographical Books and Maps, An Inventory of World Land Use (a record of work known to be in progress in different countries) and The Teaching of Geography in Schools (a factual survey). Published reports, printed or mimeographed, on all these subjects were presented; an interim note was received from the Commission for the Bibliography of Ancient Maps. A Special Committee on Conversion Tables presented a report recommending what tables should be prepared and published. Some of the reports have been published as special parts of scientific journals ; of most a small number is retained for distribution by the secretariat. An immense amount of valuable work is in progress and, despite extremely limited funds, the General Assembly agreed at its final session to the reappointment of all these commissions. In addition, the Executive Committee has set up two official commissions : one on the Mapping of Population, and the other on the Humid Tropics, to collaborate with other organizations working in these fields. Two new commissions were also approved: on National Atlases and on Applied Geomorphology.

The arrangements for the conference were excellent. The Brazilian Government made generous financial provisions which enabled a number of distinguished foreign delegates to be offered free air passages. The Navy allowed the meetings to be held, and some two hundred delegates to live, in the well-equipped Escola Naval, delightfully situated in Rio harbour on an island, now almost linked with the heart of the city by the reclaimed land on which the City airport is situated. Many nations joined in providing a magnificent map exhibition housed in the new Ministry of Education building, which also provided an auditorium equipped with simultaneous translation facilities for plenary sessions. In another building was a large selection of Brazilian maps.

The field trips arranged before and after the Congress enabled a large number of delegates to appreciate some of the problems of a vast and difficult country larger than the United States. Travelling by motor-bus over the winding mountainous dirt roads made the reason why 40 per cent of travel is by air obvious : there were times during each day when delegates saw more than one plane a minute handled by the Rio City airport. The extreme contrast between such great skyscraper cities as Belo Horizonte-their very names scarcely known to foreigners - and the vast uninhabited scrub-lands and forests impressed itself on all, while the two three-million cities of Rio and São Paulo left the impression of a growth too rapid for local administration to catch up. Everywhere the delegates met the lavish hospitality and boundless enthusiasm of the Brazilians; but standing above all was the organizing genius of Prof. Hilgard O'Reilly Stermberg and his faithful band of volunteer helpers.

At the final session of the General Assembly the presidency of the Union was handed over to Dr. Hans W:son Ahlmann, of Sweden, distinguished glaciologist, diplomat and don, and the joint invitation of the five Nordic countries of Norway, Sweden, Denmark, Finland and Iceland for the Congress of 1960 was accepted. For the past seven years the secretariat of the Union has been in the able charge of Dr. G. H. T. Kimble as secretary. treasurer : it js now to be transferred to the University of Zurich under Prof. Hans Boesch. The new Executive comprises the President, Secretary-Treasurer and Prof. Sternberg as first Vice-President, together with six Vice-Presidents-Profs. Hassan Awad (Egypt), Chauncy Harris (United States), Max Sorre (France), L. Dudley Stamp (United Kingdom), Fumio Tada (Japan), and Carl Troll (Germany).

\section{Dudley Stamp}

\section{SCIENCE AND STRATEGY}

$T$

HE modern Totalitarian Government considers itself above all moral criticism, and pursues its aims by murder by the million, routine employment of torture, the use of deliberate lies, the perversion of justice and, above all, by treating formal agreements as stopgaps to be broken whenever any least advantage is to be gained. Into this world, where good faith has almost vanished from international relationships, there has arrived the control of nuclear energy, which at the same time holds out great hopes for the improvement of man's estate and permits the construction of weapons which stand in a more extreme ratio to those of the Second World War than the latter do to the weapons of the Stone Age.

The authors of the papers in a discussion published in the Bulletin of Atomic Scientists for May, while repeating again and again the urgeney of a genuine peace, consider the functions of the Armed Services in a world where no such agreement has been reached. It is generally agreed that the H-bomb is a great deterrent; but the first contributor, Sir John Slessor, tries to see just exactly what it will deter. He concludes that global war in the 1914 or 1939 style is finished, since the object of 